\title{
Bedenin 'Estetik’ Direnişi: Modanın Muhalif Gündemleri
}

Cihan ERTAN ${ }^{1}$

\section{ÖZET}

$\mathrm{Bu}$ makale, modayı, bedenin giydirilmesine ve sunulmasına aracılık eden kıyafetleri, aksesuarları ve bedene kazandırılan biçimleri içerecek şekilde ele alarak, bir toplumsal ve kültürel fenomen olarak modanın muhalif anlamlarının izini sürmektedir. Bu bağlamda, makalenin temel amacı, direniş ve moda arasındaki ilişkiselliği tartı̧̧maya açmaktır. Bunu yaparken makale, öncelikle gündelik direnişe ilişkin kavramsal bir çerçeve sunmakta ve ardından modayı, gündelik direnişin analizinde kullanılmak üzere inşa edilen; (1) gündelik direnişin repertuvarları; (2) faillerin ilişkileri; (3) mekânsallık ve son olarak (4) gündelik direnişin zamansallığını içeren dörtlü sistematik bir yaklaşımın içine yerleştirmektedir. Genel anlamda bu çalışma, direniş çalışmaları konusunda Türkçe literatüre bir katkı sunmak amacıyla modaya yönelik, gündelik direnişin kavramsal çerçevesinden hareketle, hem amprik gözlemler hem de literatürde yer alan örnekler temelinde bir analiz yürütmektedir.

Anahtar Kelimeler: Direniş, gündelik direniş, moda, beden.

\section{'Aesthetics' Resistance of The Body: The Adversary Agendas of Fashion}

\begin{abstract}
This article traces adversary meanings of fashion, as a social and cultural phenomenon, considering it as a vehicle drawn upon for clothing and presenting the body by means of garments, accessorizes, and of stylizing. In this context, the main aim of the article is to discuss the relationality between fashion and resistance. In doing so, the article, firstly, presents a conceptual framework regarding everyday resistance and subsequently places fashion into a quartet systematical approach that is constructed in order to analyze everyday resistance consisting of (1) repertoire of everyday resistance; (2) relationships of agents; (3) spatiality, and (4) temporality of everyday resistance. In general, this study, with the aim of contributing to Turkish academic literature concerning resistance studies, analyzes fashion based both on empirical observations and on examples from literature with reference to conceptual framework of everyday resistance.
\end{abstract}

Keywords: Resistance, everyday resistance, fashion, the body.

\section{GíRiş}

Gündelik yaşamın geniş çeşitlilikteki pratikler evreni, farklı aktörlerin farklı eylemliliklerine ev sahipliği yapmaktadır. Bu farklı eylemlilikler, kimi zaman toplumsal olarak hegemonik bir biçimde tanımlanmış anlamların sınırları içerisine yerleşirken; bazen de - tam da bu yerleştikleri boşluklar içerisinden - bu sınırları zorlamakta, ihlal etmekte ve bu sınırlardan taşabilmektedirler. İktidarın ve güçlünün konumundan tanımlanan kurallara, kabullere ve normlara muhalif bir tavırla verilen karşılıklar, açık bir biçimde sergilenebildiği gibi, çoğu zaman gizli, gelip geçici, kolay fark edilemeyen, diğerinin (söz konusu bu diğeri, bazen güçlü olan bazen de genel olarak izleyen diğerleri olabilir) bakışından sıyrılan ancak yine de onun altını oyma ve ona direnme potansiyelini koruyacak biçimde sergilenmektedir (Scott, 2014). Zira, direnişte bulunan(lar)ın güçlünün karşısında hayatta kalabilmeleri

${ }^{1}$ Dr. Öğretim Üyesi, Düzce Üniversitesi, Sosyoloji Bölümü, cihanertan1@gmail.com 
için gündelik yaşamın iktidar örgüsü içinde kurnazca hareket etmekten, güçlünün inşa ettiği uzamların içinden ve onun araçlarıyla konuşmaktan başka bir seçeneği yoktur (De Certeau, 2008). İktidar, güç ve onun karşısında güçsüz ve tâbi konumda bulunanlar arasındaki bu çekişmeli mücadelede, güçsüzün ayak direyen yaratıcı toplumsal pratikleri, gündelik direniş olarak tanımlanabilmektedir.

Gündelik yaşam içerisindeki pek çok cisimleşme deneyiminden biri olarak moda, direnişin zengin bir repertuarını teşkil etmektedir. Moda ve araçları (kıyafetler, aksesuarlar, tarzlar ve bunların, bedene kazandırılan çeşitli biçimlere kaynaklık etmesi bağlamında), bireylerin toplumsal etkileşimlerinin içinde, egemen kültürün görsel ve davranıșsal kodlarına yönelik saldırgan, muhalif ve direnişçi anlamlarını sembolik olarak ifade etmeleri için bir zemin tesis etme potansiyeline sahiptir (Bennett, 2004). Modanın, aşağıda da tartışılan tüm diğer direniş biçimlerinde olduğu gibi, güç ilişkileri zemininde ortaya çıkan bu direnişçi anlamları, çok aksanlıdır. Bu bağlamda, gündelik direnişin kavramsal çerçevesinden bu anlamları ortaya çıkarmak, bu aksanlara dikkatli bir biçimde analiz etmeyi, güçlü - güçsüz ilişkiselliğini sabit kategoriler olarak ele almamayı ve sistematik bir bakış açısı benimsemeyi metodolojik olarak dayatmaktadir.

Baaz ve arkadaşlarının (2016: 149) işaret ettikleri gibi; iktidar, direniş ve toplumsal değişme, birbiriyle ilişki bir biçimde var olmaktadır; aynı zamanda, yalnızca iktidarın çalışma ve yapılanma mantığını anlamaya çalışmak, konunun diğer yarısını dışarıda bırakmak ve iktidarın rolüne gereğinden fazla vurgu yapmakla sonuçlanabilmektedir. Bununla ilgili olarak, De Certeau (2008: 48), iktidar ilişkileri bağlamında iktidarın, işleme, yayılma, disipline etme ve uygulama biçimleri üzerine yapılan fazlaca vurguyla arasına mesafe koyarak, ancak yine de onunla kuramsal ve ampirik bağını koparmadan, gündelik olanın mikro politik düzleminde ortaya çıkan, bireylerin "eylem, uygulama ve üretme" tarzlarında saklı direniş yordamlarını incelemenin önemini şu sözlerle aktarmaktadır:

' $\mathrm{Bu}$ 'eylem, uygulama ve üretme' tarzları, kullanıcıların, sosyokültürel üretim teknikleriyle düzenlenen uzamı kendilerine uydurmalarını sağlayan binlerce alışkanlığı, tutumu ve uygulamayı oluşturanlardır... önemli olan, düzenin uyguladığı şiddetin nasıl bir disiplin teknolojine dönüştüğünü belirlemek değil, gözetimin filesine giren bireylerin ya da grupların, taktiklere dayalı, dümenci, hileci ve dağınık yaratıcılıklarının şu kaçamak gizli biçimlerini toprağın altından çekip çıkarmaktır... anti-disiplinin ortaya koyduğu ağ, ... tüketicilerin kurnazlıklarıyla örülmüştür.”

Bu bağlamda, modayı da salt egemenin çıkarlarınca yönlendirilmiş ve iktidar ilişkilerinde ekonomik ve politik açıdan baskın olanın hizmetindeki bir toplumsal fenomen olarak değerlendirmek, yine onun üzerinden ifadesini bulan muhalif ve direnişçi temsillerinin görmezden gelinmesi ya da en iyi ihtimalle gözden kaçırılması tehlikesini taşımaktadır.

Buradan hareketle bu makale, modayı dar anlamda kıyafetler ve tarzların cisimleşme deneyimi kapsamına ve gündelik direnişin kavramsal çerçevesine yerleştirerek, söz konusu fenomenin, toplumsal olarak üretilen muhalif anlamlara kültürel bir zemin teşkil etmesinin dinamiklerine yönelik bir tartışma yürütmeyi hedeflemektedir. Bu amaç doğrultusunda ilk olarak, gündelik direniş tanımlanacak, ardından toplumsal bir fenomen olarak modanın önemi ve anlamı tartışılacak ve son adımda moda, gündelik direnişin kavramsal çerçevesinden hareketle ele alınacaktır.

\section{Gündelik Direnişi Kavramsallaştırmak}

Direniş pratiği, benzer bir merkez etrafında dönen, birbirine yakın karakteristik özelliklerle tanımlanmaktadır. Örneğin, Chaudhary ve arkadaşları (2017a: ix) direnişi, asimetrik bir güç ilişkisi içinde bulunan bir öznenin, nesnesini baskılamasına bağlı olarak nesnenin bu egemenliğe başkaldırı ve reddetme eyleminin süreci olarak tanımlamaktadır. Bu reddedişin hedefinde bir şey, nesne, imaj, fikir, kişi ya da grup bulunabilmektedir (Chaudhary vd., 2017b: 5). Awad ve arkadaşları ise (2017: 161) direnişi, "hakim temsillere karşı durma ve toplumsal gerçeklik üzerine bir kimsenin kendi perspektifini öne sürmesi ve olumlaması eylemi" olarak tanımlayarak; direnişin, değişimi ifade eden bir süreç ve farklı toplulukların arzuladıkları geleceklerine yönelmiş bir eylemlilik olduğuna dikkat çekmektedirler. Yer verilen tanımlama girişimlerinden anlaşılabileceği gibi; direniş, güçle ilişkili bir biçimde ortaya çıkan, birine ya da bir şeye karşı olan eylem olarak tanımlanmaktadır (Hollender \& Einwohner, 2004; Johansson \& Vinthagen 2014). Gündelik direniş, geniş ölçekli bir pratikler evrenini kapsamaktadır. Bu bağlamda, bilgisayar oyunları oynayan bir ergenin, kendi serbest zaman kullanımı ve toplumlaşma biçimleri üzerinde, gücün sembolü olarak ebeveynlerine karşı kontrol kazanma deneyiminden 
(Wearing vd., 2015); aşk romanı okuyan bir ev kadınının, domestik alana yöneltmesi beklenen zaman ve parayı, romanın kendisine yatırarak hegemonik toplumsal cinsiyet beklentilerinin altını oymasına (Fiske, 1994: 55), piercing ve dövme gibi beden modifikasyonlarının kültürel olarak idealize edilmiş beden formuna ayak direyen ve direnişle ilişkilendirilen yaşam biçimlerinin sembolik ifadeleri olarak kullanımlarından (Ertan, 2017; Pitts, 2003), kadınların saçlarına verdikleri biçimler üzerinden elde ettikleri güçlenme deneyimlerine (Weitz, 2001), çevrimiçi mizahtan, sokağın kamusal yüzünü, egemen temsillere, pratiklere ve kurumlara karşı olan söylemler üretmek amacıyla kendi estetik dilini kullanarak dönüştüren grafitiye (Awad, 2017) kadar uzanan bir kapsamda direnişin farklı formları söz konusudur.

Johansson ve Vinthagen (2014: 2), direnişin, en genel düzeyde, "karşıt bir eylem" olarak tanımlanabileceğine dikkat çekerek; bu eylemin, bir eyleyen(ler) birimini içerdiğini ve söz konusu eylemin, güçle muhalif bir ilişki içinde hayata geçirildiğini ifade etmektedirler. Burada dikkat çekilmesi gereken nokta, direnişin ilişkili bir biçimde ortaya çıktığı gücün sabit ve önceden tanımlı bir konum olmadığı; bundan ziyade, bağlamsal ve mafsallı olduğunun gözden kaçırılmaması gerektiğidir. Dolayısıyla, değişmez pozisyonlarda duran düz bir güç - direniş ilişkiselliğinden söz etmek çok mümkün değil gibi görünmektedir. Bunun en iyi örneklerinden birini, kültürel olarak idealize edilmiş erkekliğe, erkeklerin kendi içinden yükselen direniş söylem ve pratikleri teşkil etmektedir. Erkek bireylerin kendilerini bütüncül bir biçimde, ataerkil ideolojiden hareket ederek, gücün sabit konumunu temsil ettiklerini düşünmek, ataerkilliğe yönelik, erkeklerin kendilerinin sergilediği direnişi gözden kaçırmaya ya da bunu bir direniş olarak görmemeye yol açabilecek indirgemeci bir okuma potansiyeli taşımaktadır. Bu bağlamda direniş, güç ilişkilerinin zemininde karșı karşıya gelen iki homojen toplumsal biriminin tek yönlü ilişkileri olarak anlaşılmamalıdır. Bundan ziyade direnişin, direnen(ler)in, direnişte bulunulanın (hedef) ve diğer gözlemcilerin arasındaki çok yönlü ve katmanlı etkileşimlerini ve anlamlandırmalarını içeren bir süreç olduğuna ilişkin bir değerlendirmeye ihtiyacı vardır (Johansson \& Vinthagen, 2014; Baaz vd., 2016). Bu, çok taraflı etkileşimsel çerçeve içinde direniş, bağlamsallık, uzamsallık, aktör ve kullanılan teknikler düzeyinde ortaya çıkan farklılıklar düzleminde ele alınmalıdır.

Gündelik direniş ve mikro karakterinin söz edilen çok yönlü doğası göz önünde bulundurulduğunda, onu çözümlemek ve anlamak konusunda kavramsal bir çerçeveye yönelik bir ihtiyaç ortaya çıkmaktadır. Bu makale, direnişe kaynaklık eden kültürel bir pratik ve fenomen olarak modaya ilişkin bir okuma gerçekleştirirken, Johansson ve Vinthagen'in (2014) direnişi çözümlemek için ortaya koydukları kavramsal çerçevesini hareket noktası olarak kullanacaktır. Bununla beraber makale, hem genel anlamda Türkçe literatürde az rastlanan gündelik direniş çalışmalarındaki boşluğa hem de gündelik direniş ve moda ilişkiselliğine yönelik alana kavramsal bir katkı sunmayı hedeflemektedir.

Johansson ve Vinthagen (2014: 3), gündelik direniş analizinde, direniş gösterenin kim olduğu, kiminle ilişkili bir biçimde direniş sergilediği, bunun nerede, ne zaman ve nasıl ortaya çıktığı sorularının, analizin sınırlarını belirlemek konusundaki önemine dikkat çekmektedirler. Tüm bu sorularla bağlantılı olarak, direnişe ilişsin 4 boyuttan oluşan bir çerçeve ortaya çıkmaktadır: (1) Gündelik direnişin repertuvarları; (2) Faillerin ilişkileri; (3) Mekânsallık ve son olarak (4) Gündelik direnişin zamansallı̆̆ 1 .

Modayı, direnişe kaynaklık eden zengin bir alan olarak konumlama tartışmasına geçmeden önce, yukarıda söz edilen dört boyutlu kavramsallaştırmanın her bir boyutunun ne anlama geldiğini ve neye işaret ettiklerini aydınlatmak anlamlı görülmektedir. Gündelik direnişin repertuvarı, bir direniş analizindeki, çeşitli iktidar biçimlerinin ürettiği ve onlara yönelik direnişin farklılaşan karakterine işaret eden boyutuna göndermede bulunmaktadır. Başka bir ifadeyle, bir repertuvar, direniş eylemine kaynaklık eden, belirli toplumsal koşullara, hedefindeki gücün formuna ve bireysel yaşam deneyimlerine bağlı teknikleri, taktikleri ve araçları içermektedir (Johansson \& Vinthagen, 2014: 6). Bununla beraber, direniş sergilenen karşıt gücün belirli bir formu, direnişin taktikleri ve içeriği üzerinde etkili olabilmektedir ya da bir güç odağına yönelik direnişin repertuvarı, farklı örneklerde çeşitli biçimler kazanabilmektedir. Bu bağlamda, farklılaşan direniş repertuvarları şiddetlilik (gerilla grupları, radikal dini hareketlerin silahlı eylemleri vb.) ya da şiddetsizlik (boykotlar, oturma eylemleri, sivil itaatsizlik, hayvan hakları aktivizmi vb.), organize ya da organize olmamış ve estetik taktiklerle donanmış pratikler (kültürel metinlerin üretimi, eleştirel sanatsal faaliyetler, modanın kaynaklığında tarz üzerinden ifadesini bulan kimlik hareketleri vb.) olarak sinıflandırılabilir (Baaz vd., 2016: 145). Faillerin ilişkileri, Johansson ve Vinthagen'in işaret ettiği gibi (2014: 6 - 8), direniş gösterenin kim 
olduğu, biçimi (kolektif ya da bireysel), kime karşı direniş gösterdiğini içermekle beraber; direnişçi aktör(ler), hedefi ve bu ikili etkileşime tanıklık eden diğerleri arasındaki ilişkiler boyutunu kapsamaktadır. Buna ek olarak, tarafların ilişki türleri (ebeveyn - çocuk, eş ya da partner, arkadaş, iş yerindeki meslektaşlar vb.), ilişkinin yoğunluğu, ilişkide olma biçimleri (örneğin, sanal ya da yüz yüze) ve karşılaşma bağlamları gibi unsurlar, bu boyutun kapsamında değerlendirilmektedir. Mekânsallık boyutu, direnişin ortaya çıktığı konuma, yere, başka bir ifadeyle uzamsal bağlama göndermede bulunmaktadır. Bir direnişin her zaman için bir uzamı söz konusudur ve bu uzamsallık, kimi zaman iş yerini, kimi zaman sokak ve onun farklı mekânlarını, bir evi, bir alışveriș merkezini ve bedeni içerebilmektedir (Johansson \& Vinthagen, 2014: 9 - 10). Son olarak gündelik direnişin zamansallığl, hem direnişin ortaya çıktığı zaman boyutuna hem de direnişin pratiğe dökülmesinde zamanın araçsal rolüne işaret etmektedir (Johansson \& Vinthagen, 2014: 10). Bu bağlamda ilk olarak, iktidarın her yerde ve her zamanlılığından farklı olarak; gündelik direnişin zaman içindeki varlığının, daha gelip geçici ve anlık olduğu ifade edilebilir. Kendini var ettiği bağlam içerisinde bir direniş pratiği, anlık olarak ortaya çıkıp son bulabilir. Bununla beraber, zamansallığın ikinci boyutu olarak direniş, zamanın iktidar odaklı organizasyonu içinde kendi zaman örgütlenmesini yaratma yoluyla ortaya çıkabilmektedir. İş yavaşlatma, işe geç gitme ve erken çıkma gibi pratikler üzerinden zamandan çalma gibi eylemler, üretkenlik odaklı iktidar tanımlı zamanı tersine döndüren ve üretkenliği azaltmaya yönelik direniş eylemlerine örnek olarak gösterilebilir (Baaz vd., 2016: 147; Johansson \& Vinthagen, 2014: 12). Gündelik yaşamı güçlü ve güçsüz konumları arasında verilen bir mücadele alanı olarak görmenin ve buradan hareketle mikro direniş pratiklerine ilişkin bu kavramsal çerçevenin ilk yankıları, De Certeau'da da (2008) görülebilmektedir. De Certeau (2008: 46), tüketicinin her türden kültürel metni (televizyon, mekân, yemek yapmak vs.) kendi tüketim yordamlarına dahil ederek yeniden yorumladığını ve bu pratik çeşitliliğinin, kurnazlık, aldatmaca, sıyrılma ve oyuna getirme gibi taktikler çerçevesinde örgütlenen bir direnişi içerdiğine dikkat çekmektedir. Özellikle tüketim üzerinden kendini var eden bir üretim sürecine odaklanmak suretiyle De Certeau (2008: 46), mikro direnişi bir dillendirme pratiği meselesi olarak ortaya koymakta ve bu dillendirmenin, bir dil sistemi içinde işlediğini (kendine özgün bir söz dağarcığı içinden konuşmak), dili kullananların benimseme ve yeniden - benimseme süreçleriyle ilgili olduğunu, belirli bir anda şimdilik zaman kurgusu yarattığını ve öteki ile ilişki içinde belirli bir mekânsallık içerdiğini ileri sürmektedir. Başka bir ifadeyle De Certeau (2008), gündelik mikro direniş pratiklerinin, çok aksanlılığına, aktörleri arasındaki ilişkilerine, zamansallığına ve mekânsallığına, dilbiliminden ödünç aldığı kavramsal analojilerle temas etmektedir. Yukarıda söz edilen gündelik mikro direnişin dört boyutu, değişmez kategoriler olmaktan ziyade, direniş pratiklerinin analizinde kullanılabilecek analitik bir çerçeve sunmaktadır. Bununla beraber bu dört boyut, birbirinden ayrı olarak düşünülemeyecek kadar girift karaktere sahiptir. Scott'un (2014: 43 - 44) örneğini verdiği şekliyle, toprak sahibi ve köylü arasındaki sınıfsal mücadelenin mikro görünümünde köylünün, iktidar ilişkilerinin altını oymaya yönelik "yasak bölgede avlanma, hırsızlık, el altından vergi kaçırma ve toprak sahipleri için kasıtlı olarak kötü iş yapma" türünden pratikler, belirli bir repertuvar, failler arası ilişki, mekânsallık ve zamansallık içermektedir. Bu bağlamda, her bir boyut arasındaki çok yönlü ve doğrusal olmayan bir etkileşim ve her birinin aynı anda diğerleri üzerindeki etkisi söz konusudur.

Makalenin bundan sonraki bölümleri, sırayla modayı kavramsal olarak sosyolojik bir çerçevede ele alacak, ardından toplumsal ve kültürel bir fenomen olarak modayı direnişe ilişkin dört boyutlu kavramsal - sistematik zemine yerleştirip, onun cisimleşme deneyimlerini merkeze çekerek; beden, moda ve direnişe ilişkin bir tartışma yürütecektir.

\section{Modayı Tanımlama Çabası ve Modanın Toplumsal Önemi}

Biyolojik bir varlık olmasının yanında ve onu aşan bir biçimde beden, aynı zamanda, var oluşun kültür kipinden ifadesini bulduğu bir zemindir. Dolayısıyla beden, O'Neill'in (2004: 6) dikkat çektiği gibi, hem daha küçük hem de daha geniş toplumsal formasyonlar içerisinde, sembolik anlamlarla yüklü, birey - toplum arasındaki bağın cisimleşmiş biçimlerinin görünür olduğu, toplumsal düzenin üzerine yazıldığı ya da bunun reddedilmesine aracılık eden, süslenme, giyinme, yemek yeme, selamlaşma gibi sayısız pratiklerle toplumsallığının yönetildiği sosyo-kültürel bir olgudur. Bu bağlamda, toplumsalın çok yönlü ilişkiselliğinin merkezinde olan beden, bir kimliklenme, benlik inşa etme aracı olmakla 
beraber; bireyin, kendini ifade etmesinin ve toplumsal olana eklemlenmesinin de yaratıc bir zeminini oluşturmaktadır (Giddens, 2014; Ertan, 2017).

Beden dolayımıyla ve çeşitli araçların yardımıyla (kıyafet, saç şekli, beden modifikasyonları, geçiş ritüelleri, spor vb.) üretilen anlam ve ifadeler, bütünlüklü bir bakışla cisimleşme deneyimleri olarak kavramsallaştırılabilirler. Bu bağlamda moda, bedenin cisimleşme deneyiminin zengin repertuarının önemli bir yönünü oluşturmaktadır. Modanın beden dolayımıyla gerçekleşen cisimleşme deneyimi, Simmel'e göre (1957) iki önemli açıdan önemlidir. Simmel (1957), bireylerin yaşamlarının, tatmin edilmeyi bekleyen, toplumsal uyum ve toplumsal taleplerden sapmanın çelişkili ihtiyacıyla karakterize olan iki kutuplu bir gerilim içerisinde ilerlediğini ifade etmektedir. Moda, taklit etme üzerinden uyum, güvenlik ve bir aradalığa ilişkin bir tatminiyet; aynı zamanda da hem yaygın olan üzerinde yapılan değişiklikler (topuk boyunu uzatma, pantolon paçasını kısaltma vb.) hem de tamamen yaygın olandan ayrılan farklı kıyafet kodlarının benimsenmesiyle ayrışma, farklılaşma ve kabul edilen genelden uzaklaşma ihtiyacına aynı anda yanıt vermesiyle sosyolojik açıdan önemli görülmektedir: "Modanın ortaya çıkmasında iki toplumsal eğilim asıldır, bir tarafta birlik, birleşme ihtiyacı, diğer tarafta da izole olma ve soyutlanma ihtiyac1" (Simmel, 1957: 546).

Modanın aracılık ettiği toplumsal farklılaşma, salt tarza dayanan bir mantıkta değil; bir yandan da sınıfsal ayrışmanın ifadesi olmasında karşılığını bulmaktadır. Bu bağlamda moda, sınıfsal tabakalaşmanın bir sonucudur. Bir sistem olarak moda bir yandan sınıfsal ayrışmanın mantığını inşa ederken (Blumer, 1969: 281); onun ürünlerinin tüketimi, aynı sınıftan kişilerin birliğine, bir çevrenin benzerliğine ve diğer bütün grupların dışlanmasına işaret etmektedir (Simmel, 1957: 544). Modanın sınıfsal karakterine ilişkin benzer kavramsal bir yakınsamaya, metalara yönelik olarak yapılan gösterişçi harcamaların en iyi bir biçimde giysiler üzerinden sergilenebileceğini öne süren, dolayısıyla modaya uygunluk ve sınıfsal saygınlık arasındaki ilişkiye dikkat çeken Veblenci (2016) sosyolojide ve kıyafete, parfümlere, aksesuarlara yapılan harcamaların ve bunlara yönelik tercihlerin sınıfsal konumların sembolik göstergeleri olduğuna vurguda bulunan Bourdieu'nun (2015) düşüncelerinde de rastlanmaktadır.

Modayı sosyolojik olarak kavramsallaştırma, üretim, dağıtım ve tüketim koşulları çerçevesindeki hareket yönlerini tayin etme konusunda, yukarıdan - aşă̆l ve tabandan - yukarl olmak üzere, iki modelin temel alındığ 1 ifade edilebilir. Bunlardan ilki, modanın, onun sınıfsal karakterine yapılan vurguyla bağlantılı bir biçimde, endüstriyel olarak, seçkin bir grup tarafından üretildiğinin ve toplumun daha aşağı kesimlerine doğru kademeli olarak hareket halinde olduğuna işaret etmektedir. Yukarıda söz edildiği gibi; Simmel (1957), Veblen (2016) ve Bourdieu'nun (2015) kuramsal yaklaşımlarının bu modele dayandığı ileri sürülebilir. Örneğin Simmel (1957), modaya toplumun ekonomik açıdan ayrıcalıklı bir grubun yön verdiğini; bununla birlikte, moda olan ürünlerin ilk olarak toplumsal katmanlaşmanın en üst kademesinde tüketildiğini, ardından diğer alt tabakalara; sırasını, sınıfsal anlamda kendisine en yakın olma prensibinden alarak, kademeli bir şekilde yayıldığını, yayılım başlar başlamaz da üst tabakaların takip ettiği modanın çoktan terk edilmiş olduğunu ifade etmektedir. Bu bağlamda, söz konusu model çerçevesinde moda, soyut bir güç tarafından merkezi bir biçimde üretilen giysiler ve tarzların egemen formları olarak kavranmaktadır (Buckley \& Clark, 2016). İkinci model, tabandan - yukarl, tepeden belirlenimci yaklaşım benimsemenin aksine, modaya ve onun gündemine kaynaklık eden yaratıcı bir toplumsal güç olarak, sıradan hatta düşük statü grupların tarzlarına, beğenilerine, giysi ve aksesuarları tüketme yordamlarındaki otantikliğe dikkati çekmektedir. Söz konusu model çerçevesinde, marjda görülen; punk, rock, metal gibi müzikal türler etrafında örgütlenmiş altkültürler merkeze çekilmekte ve bu altkültürlerin tarz repertuvarlarının kendi özgün modalarını üretme ve bir sistem olarak modaya kaynaklık etme potansiyellerine vurguda bulunulmaktadir.

Modanın sunduğu seçeneklerin çeşitliliği aracılığıyla bireyler, salt bedenleri örtmekle kalmamakta; bundan ziyade ve bunun ötesinde, benlik ifadesinin, kimlik inşa etmenin, diğerleriyle etkileşime geçmenin, görülmenin ve görmenin, direniş sergilemenin, uyum göstermenin ve sapmanın farklı olanaklarına erişmektedirler ve dolayısıyla moda, tüm bu özellikler çerçevesinde tanımlanmaktadır (Busch, 2007; Jenns, 2016; Davis, 1997). Wilson (2003: 15), modanın "modernist bir ironi” olduğuna işaret etmektedir. Bunun anlamı, modern kapitalizmin kitlesel üretim mantığına sıkı bir biçimde bağlı olan modanın, bir taraftan zenginlikle ilişkili olduğu, diğer yandan herkesin erişimine açık geniş bir tüketim evreni olduğu, bir yandan toplumsal cinsiyet temelinde estetik ve güzellik ideallerini üreten, dayatan ve yeniden üreten, diğer bir taraftan buna meydan okuyan politik ve kültürel bir aracı teşkil 
ettiği, bir taraftan metalaştırıcı olduğu, diğer taraftan özgürleşmeye ve güçlenmeye zemin oluşturduğudur.

Dolayısıyla, Crane'nin de (2003) dikkat çektiği gibi, geç modern dönemde tek bir 'moda'dan değil; 'modalar' dan söz etmek daha isabetli görünmektedir. Zira, söz konusu olan modalar ya da modanın içindeki eğilimler ya da akımlardır. Bu, büyük oranda; farklılıkların, yaşam biçimlerinin, tarzların ve tüm bunların bir çıktısı olarak; kendini ifade etme yollarının fazlalığının bir sonucudur. Modayı, tüm bu seçeneklerin kendisinden çıktığı ve onları barındıran kültürel bir tüketim alanı olarak görmek, onun dinamiklerini ve çelişkili karakterini kavramak açısından önemlidir. Bu çelişkili karakteri, tutarsızlığa işaret etmekten ziyade, tüketimin kendine içkin bir özelliği olarak değerlendirmek yerinde olacaktır. Zira, kültürel metinlerin evreni içerisinde gerçekleşen tüketim, kimi zaman hegemonik anlamlarla işbirliği içinde olabilirken, kimi zaman onlara direnen karşıt anlamları üretmektedir. Bununla beraber, tüketim sırasında üretilen muhalif anlamların, muhalefetin hedefinde olanın ürettikleri üzerinden türetiliyor olması da bu çelişkinin ikinci katmanını teşkil etmektedir. Kültürel bir metin olarak moda da tüm bu çelişkileri barındıran, bireylerin bu çelişkili tüketim yordamları içerisinden kendilerini ifade ettikleri bir olgudur. Bu makalenin genel çerçevesi kapsamında mercek altına alınan konuyu, modanın tüketim aksanlarından (De Certeau, 2008) biri olan gündelik direnişle olan ilişkiselliği oluşturmaktadır.

\section{Direnişin 'Estetik’ Formu: Moda, Beden ve Karşıt Kültürel Pratikler}

Toplumsal bir fenomen olarak modaya ilişkin çizilen kavramsal çerçevede söz edildiği gibi, kültürel bir ifade biçimi bağlamında modanın ortaya çıkış ve hareket yönü konusunda, 'yukarıdan - aşağı' ve 'tabandan - yukarı' olmak üzere iki temel yaklaşımın hâkim olduğu ifade edilebilir. Daha önce de öne sürüldüğü gibi, yukarıdan - aşağı model modanın tanımlanma ve yayılma noktasını ayrıcalıklı bir üst sınıfa atfederken, örtük olarak politik ve ekonomik gücü de modayla kaçınılmaz bir biçimde ilişkilendirme eğilimi göstermektedir. Bunun yanında, modanın tabandan yukarıya modeli, halkın, özellikle tabandaki güçsüzün kendi özgün tüketim aksanlarının modaya kaynaklık ettiğini ileri sürerken, gücün pozisyonunu değiştirmemekte ancak halkın içinden sıradan bireylerin, gündelik yaşam içerisinde, moda etrafındaki dinamiklerine ve bunların beden dolayımlı cisimleşme deneyimlerinin, tepeden tanımlananı aşan bir kimliklenme stratejisi ve kültürel ifade araçları olabileceğine dikkat çekmektedir.

Modanın gündelik direnişle olan keşisimselliğinin izleri, tam da direnişin bağlamsal karakterinden ve aktörün güçle olan ve güç içindeki pozisyonun oynaklığından dolayı, her iki yaklaşım içerisinde de görülebilmektedir. Zira, güç ve tabiiyetin sabit toplumsal konumlar olmadiğ 1 , her ne kadar içinden çıkan pratiğin göze alması gereken sonuçları itibariyle farklılaşsalar da, 'dikte eden' ve 'dikte edilen' arasındaki sınırların muğlak olduğu ve bunların, en iyi ihtimalle etkileşimsel ve bağlamsal olarak düşünülmesi gerektiği ileri sürülebilir (Scott, 2014). Moda ve onun cisimleşme pratiklerinde direnişin izlerini sürmek de gücü sabit bir kategori olarak görmemeyi dayatmaktadır. Bu bağlamda, gündelik direnişe ilişsin olarak yukarıda çizilen kavramsal çerçeve, direniş pratiklerini moda cinsinden okumak konusunda oldukça analitik bir yol sunmaktadır. Zira, gücün farz edilen sabit pozisyonu içinden bireylerin de moda aracılığıyla direniş eylemi sergileyebileceğini düşünmemenin hiçbir nedeni bulunmamaktadir.

Moda, Blumer'in (1969) işaret ettiğinin tersine; kıyafet, aksesuar, beden modifikasyonları ve bunlar üzerinden inşa edilen tarzlara aracılık eden cisimleşme deneyimleri çerçevesinde ele alındığında, her şeyden önce onun üzerinden sergilenen direnişin repertuvarının da genel olarak bu kıyafetler ve bedene yönelik müdahalelerden oluştuğu ifade edilebilir. Bu bağlamda modanın aracılığında ortaya çıkan direnişin repertuvarı, şiddetsizlikle karakterize olan, organize olmamış ancak yüksek düzeyde estetikle ilişkilendirilmiş taktiksel beden pratiklerini ve obje kullanımlarını kapsamaktadır. Burada önemli olan nokta, kıyafetlerin, aksesuarların ya da bedenlerin, muhalif anlamlar üretecek biçimde nasıl kullanıma sokulduğudur. Bir başka ifadeyle söz konusu olan, Chaudry ve arkadaşlarının da (2017b: 6) ifade ettikleri gibi; bireylerin aktif olarak, nesneleri belirli bir modanın ifadesi olacak bir biçimde ve muhalif bir zemine yerleştirerek, önceden atfedilmiş anlamlarının dışına taşırarak gerçekliği dönüştürme girişimleridir. Modanın direnişçi repertuvarına örnek olarak, 19. yüzyıl'dan itibaren kadınların, erkek giysilerine ait parçaları eklektik bir biçimde kendi bedenlerinde bir araya getirmesi verilebilir. Kadın bedeninde cisimleşen bu melez ve eklektik moda anlayışı (kadınların kravat takması, pantolon giymesi vb.), kıyafetlerin salt bir arada kullanımına değil; yüksek düzeyde politik bir pratik olarak toplumsal 
cinsiyet eşitliğine, bağımsızlığa, muhalif bir yaşam tarzının ifadesine ve sisteme yönelik bir başkaldırıya işaret etmektedir (Crane, 2003: 134 - 136). Bununla beraber, başka bir çarpıcı örneği de, altkültürel tarzlar ve üyelerinin, nesnelerin hakim anlamlarına kendi modaları içerisinde farklı aksanlılıklar katması oluşturmaktadır. Örneğin mod tarzının, kapitalizm etrafında örgütlenmiş iş dünyasının işaretleri olarak ceket, takım elbise, kravat, kısa saç ve onların sembolik olarak temsil ettiği otoriteye uyum, üretkenlik gibi anlamlarını "boş fetişler" haline getirmesinden ya da punk modasının, çengelli iğneyi ev içi kullanım alanından çıkartıp kulak, kaş, çene ve dudakta, kültürel olarak idealize edilmiş bedensel formu ters-yüz etmek amacıyla kullanılmak üzere bir aksesuara dönüştürmesinden söz edilebilir (Hebdige, 2004: 100 - 101).

Yukarıda verilen örnekler, modanın direnişçi anlamları bağlamında, kimlerin, ne şekilde direniş gösterdiğini ve tarafların karşılaşma biçimlerini içeren, birbiriyle yüksek düzeyde geçişlilik içerisinde olan mekânsallık ve failler arasındaki ilişkiler boyutlarını da kapsamaktadır. Moda üzerinden sergilenen direniş, kimi zaman, yukarıda söz edildiği gibi, altkültürel sembolik ortak bir dilin kolektivizmi altında gerçekleşebilirken, kimi zaman da kolektif bir kimliğin kesin göstergelerini taşımayacak bir biçimde daha dağınık, başka bir ifadeyle görece daha az örgütlü ve bireysel bir görünüme sahip olabilmektedir. Bir kadının kısa saç üzerinden elde ettiği güçlenme deneyimi, moda üzerinden sergilenen bireysel direniş biçiminin bir örneğini teşkil etmektedir. Failler arası ilişkiler kapsamında, modanın farklılaşan repertuvarı aracılığıyla gösterilen direnişin güç ilişkileri içindeki hedefi ve direnişin çıkış noktası da farklılaşabilmektedir. Burada iki önemli nokta dikkati çekmektedir. İlk olarak moda üzerinden direniş, modanın üreticilerinin sağladığı metaların, direnişçi anlamlarla donatılacak biçimde tüketiciler tarafından bir yeniden anlamlandırma sürecine dahil edilmesi; ikinci olarak, direnişçi anlamların, çoğu zaman gücün sabit konumu olarak düşünülen toplumsal gruplardan ve modanın üreticilerden de çıkabiliyor olması. Bu bağlamda, hedef olarak güç ve direnişin çıkış noktası, mekânları sabit kategoriler olarak değerlendirilmemelidir. İlkine örnek olarak yine hegemonya karşıtı altkültürel modalara dönüş yapılabilir. Akay ve arkadaşlarının (1995: 168 - 171) 1990'larda yükselişe geçen İstanbul Grunge müzik sahnesi ve modasına ilişkin olarak ifade ettikleri gibi; paranın ve zenginliğin göstergesi olarak iyi ve "temiz giyim"le karaterize olan "TİKI" modasına karşıt bir pozisyonda kendini tanımlayan bu kültür, "asker postalları, deri ve süet ceketler, free bag'ler, eski ve yırtık blue jean'ler, oduncu gömlekleri ve etiketleri sökülerek kullanılan markalı giysileriyle" bir direnişin ifadesi halini alan moda karşıtı bir moda olarak gündelik direnişin sahnesinde boy göstermiştir.

Güce sabit bir konum atfetmek ya da bir konumu, onda sabit kalacak bir güç üzerinden tanımlamak, moda üzerinden ifade edilen direnişi görmek ve analiz etmek konusunda bir engel oluşturmaktadır. Bunun etkili örneklerinden biri, Kaiser ve Green'in (2016), moda üzerinden tesis edilen erkekliklerle ilgili araştırmasında görülebilmektedir. Kaiser ve Green (2016: 171 - 172), hegemonik erkekliğin kültürel kodları içinden kendini tanımlayan erkeklerin, kendilerini bakışın nesnesi hâline getireceğini düşündükleri tarzları reddederek, bakımlı olmak ve dikkat çekici bir şekilde dış görünüşe ilgi göstermekle karakterize olan metroseksüel erkekliğe karşı durduklarını ifade etmektedirler. Açık bir şekilde görülebileceği gibi; tarz üzerinden ifadesini bulan direniş, gücün toplumsal olarak konumlandırıldığ 1 bir pozisyonundan ortaya çıkmaktadır. Eğer direniş, her zaman güce yönelik bir eylemlilik olarak düşünülürse, tam da onun içinden çıkan direnişin taktiklerinin, yapısının ve hedeflerinin de gözden kaçırılması söz konusu olacaktır. Dolayısıyla, gücün toplumsal olarak nerede yapılandırıldığı önemli olduğu kadar, bu yapılandırmanın dışında, bireylerin bu güç ilişkileri içinde kendini nerede konumladıkları, onların neye güç atfederek direniş eylemliliklerinin hedefi haline getirdikleri de önemlidir. Bununla beraber direnişin, modanın üretici gücünün içinden de kaynağını bulabildiği gerçeği söz konusudur. Örneğin, Rihanna'ya (Rudzinski \& Orabona, 2020) ait kadın iç çamaşırı koleksiyonunun, bir gösteriye dönüştürülerek izleyiciyle buluşturulduğu Savage X Fenty Show Vol. 2, modanın kendisine atfedilen güçlü pozisyonu içinden konuşmakta ancak bu dil, pek çok açıdan hegemonik kültürel kodlarla karşıtlık içindedir. Söz konusu moda temsili içinde, yine modanın kendisi tarafından tanımlanan hegemonik beden estetiğinin dışında ve marjda kalan yağ oranı yüksek, trans ve androjen bedenler merkeze çekilmektedir. Bununla beraber modanın, sadece beyaz, heteroseküel cinselliğin değil; cinselliğin kendisinin, ırk ve yönelim üstü bir şekilde kutsandığı, tüm farkl1lıkları kapsayan ve temsil eden söylemsel bir araca dönüştürüldügü görülmektedir. Tüm bunlar, modanın dışlayıcı yönüne yine modanın kendi içinden verilen bir yanıt olarak düşünülebilir. 
Dolayısıyla moda üzerinden üretilen direnişin failleri gündelik yaşam içerisinde, mekânsal olarak kimi zaman iletişim araçlarının sanallığı, kimi zaman sokağın fizikselliği içinde etkileşime geçmektedirler. Son olarak modanın, direnişin zamansallığının sistematik çerçevesine yerleştirilmesi konusunda iki nokta tartışmaya açılabilir. Bunlardan ilki, örgütlü ve görece daha koordinasyonlu (Hollender \& Einwohner, 2004) direniş biçimlerine göre (örneğin, sokak protestoları) daha kısa süreli ve anlık olma özelliği taşıyan bir zamansallık içerdiği ifade edilebilir. Zira, muhalif bir tarzın direniş potansiyeli, her ne kadar failin cisimleşme deneyiminin karşıt anlamı yalnızca buna dayanmasa da; bir bakıma izleyen diğerlerinin o anda bu bedensel sunumu kültürel bir tehdit olarak görmelerine bağlı olacaktır. Bu bağlamda, modanın direnişçi anlamlarının zamanın küçük parçalara ayrılmış bölmelerine yuvalanmış ve ortaya çıkmak için firsat kollayan bir karakter taşıdığını ileri sürmek mümkündür. Moda ve direnişin zamansallığı arasındaki bu ilişkiyi daha açık ifade etmek gerekirse; örneğin, bir kıyafet, taşıyan tarafından direniş niyetiyle tüketilmediği halde, aynı zamansallığı paylaşan diğerleri tarafından, "kasıtsız direniş" üretecek biçimde (Hollender \& Einwohner, 2004: 545), bir tehdit olarak görülebilir. Bununla beraber, tam tersi bir şekilde, direniş anlamı üretmek için modanın cisimleşme deneyimine baş vuran başka bir kişinin pratiği de o anda hedefi tarafından fark edilmeyebilir ve "örtük direniş" (Hollender \& Einwohner, 2004: 545) yaratabilir. Tüm bunlara ek olarak moda, zamanın kullanım biçiminin, onunla oynamanın, yeniyi, eskinin kullanımıyla reddetmenin taktiksel ve yaratıcı bir aracını teşkil etmektedir. Örneğin, McRobbie'nin (2013: 197) de retro tarzıyla ilintili belirttiği gibi; ikinci el ve nostaljik kıyafetler, aksesuarlar ve stillerin kullanımı, “... tarihi, tarihsel olmayan şimdiki zamana çekmenin bir yolu olarak", anakronistik parçaların şimdinin içinde eklektik biçimde bir araya getirilmesiyle tesis edilen zaman üzerindeki hakimiyetin cisimleşme deneyimi şeklinde yorumlanabilir.

\section{SONUÇ}

Moda, gündelik yaşamın etkileşimsel alanı içerisinde bireylerin, bedenin sembolik fizikselliğinden hareketle kendilerini sunmalarının ve çeşitli biçimlerde ifade etmelerinin zengin bir aracıdır. Bu bağlamda moda, yalnızca bireyleri farklılaştırıcı ve onların otantik tüketim yordamlarını icra ettikleri bir mecra değildir. Bunun ötesinde, bu bedensel sembolik ifadelerin bir yönünü, direniş anlamıyla donatılmış, hedef aldığı güç odağının altını oymaya çalışan anlam çerçeveleri oluşturmaktadır. Yukarıda yürütülen tartışmalardan da görülebileceği gibi; muhalif modaların hedefi olan gücü, statik bir kategori olarak düşünmek, direniş anlamı üreten pratikleri gözden kaçırmaya neden olabilecek indirgemeci bir bakışa neden olabilmektedir. Bu bağlamda, modanın yukarıdan - aşağ ve tabandan yukarı kavramsallaştırmaları, onu hareket yönü ve üretim merkezleri yönünde anlamayı mümkün kılarken, güçle ilişkili bir biçimde ortaya çıkan direniş anlamları bağlamında oldukça sınırlı bir çerçeve sunmaktadır. Zira, hem modanın yukarıdan - aşă̆ $ı$ modelinde hem de tabandan - yukarı modelinde gücün sabit mekânı olarak, üretici ayrıcalıklı bir gruba işaret edilmektedir ve dolayısıyla hedefin, her zaman üretici güç çerçevesinde tanımlanması gerekliliği doğmaktadır. Oysa ki makale çerçevesinde yürütülen tartışmalardan ve verilen örneklerden de anlaşılacağı gibi; moda üzerinden sergilenen direniş, güçlü - güçsüz ayrımının sabit pozisyonlarından hareketle analiz edilemeyecek kadar karmaşık ve hatta kimi zaman çelişkili bir karakter sergilemektedir. Bu bağlamda, direniş, yukarıda da tartışıldığı gibi; modanın üretici konumundaki aktörleri ya da egemen pozisyondaki toplumsal grupların üyeleri tarafından da sergilenebilmektedir. Dolayısıyla, moda ve direnişi, salt gücün pozisyonu cinsinden değil; direniş anlamı taşıyan pratiğin neyi güç olarak tanımladığı, onu zayıflatmaya ve altını oymaya yönelik harekete geçirdiği taktiklerin cinsinden değerlendirmek, daha analitik bir çerçeve sunuyor görünmektedir. 
Akay, A., Fırat, D., Kutlukan, M., \& Göktürk, P. (1995). Istanbul'da Rock Hayatı: Sosyolojik Bir Bakış. İstanbul: Bağlam Yayınları.

Awad, S. H., Wagoner, B., \& Glaveanu, V. (2017). The Street Art of Resistance. İçinde N. Chaudhary, P. Hviid, G. Marsico, \& J. W. Villadsen (Ed.), Resistance in Everyday Life (ss. 161 - 180). Singapore: Springer.

Baaz, M.; Lilja, M.; Schulz, M. \& Vinthagen, S. (2016). Defining and Analyzing Resistance: Possible Entrances to the Study of Subversive Practices. Alternatives: Global, Local, Political, 41(3), $137-153$.

Bennett, A., \& Harris - Kahn, K. (2004). Introduction. İçinde A. Bennett \& K. Kahn - Harris (Ed.), After Subculture: Critical Studies in Conptemporary Youth Culture (ss. 1 - 18). New Yok: Palgrave Macmillan.

Blumer, H. (1969). Fashion: From Class Differentiation to Collective Selection. The Sociological Quartely, 10(3), 275 - 291.

Bourdieu, P. (2015). Ayrım: Beğeni Yargısının Toplumsal Eleştirisi. Ankara: Heretik Yayınları.

Buckley, C., \& Clark, H. (2016). In Search of the Everyday: Museums, Collections, and Representation of Fashion in London and New York. İçinde H. Jenss (Ed.), Fashion Studies: Research Methods, Sites and Practices (ss. 25 - 42). London: Bloomsbury Academic.

Busch, O. V. (2017). Moda Praksisi. İstanbul: Yeni İnsan Yayınevi.

Chaudhary, N., Hviid, P., Marsico, G., \& Villadsen, J. W. (2017a). Foreword. Resistance in Everyday Life (pp. vii - xii). Singapore: Springer.

Chaudhary, N., Hviid, P., Marsico, G., \& Villadsen, J. W. (2017b). Rhythms of Resistance and Existance: An Introduction. İçinde N. Chaudhary; P. Hviid; G. Marsico \& J. W. Villadsen (Eds.), Resistance in Everyday Life (ss. 1 - 9). Singapore: Springer.

Crane, D. (2003). Moda ve Gündemleri: Giyimde Sinıf, Cinsiyet ve Kimlik. İstanbul: Ayrıntı Yayınları.

Davis, F. (1997). Moda, Kültür ve Kimlik. İstanbul: Yap1 Kredi Yayınları.

De Certeau, M. (2008). Gündelik Hayatın Keşfi - I: Eylem, Uygulama, Üretim Sanatları. Ankara: Dost Yayınevi.

Ertan, C. (2017). Dövmeli Bedenler: Bir Beden Sosyolojisi Kitabı. Ankara: Pheonix Yayınevi.

Fiske, J. (1994). Understanding Popular Culture. London: Routledge.

Giddens, A. (2014). Modernite ve Bireysel - Kimlik: Geç Modern Çă̆da Benlik ve Toplum. İstanbul: Say Yayınlar.

Hebdige, D. (2004). Altkültür: Tarzın Anlamı. İstanbul: Babil Yayınları.

Hollender, J. A., \& Einwohner, R. L. (2004). Conceptualizing Resistance. Sociological Forum, $19(4), 533-554$.

Jenss, H. (2016). Introduction. H. Jenss (Ed.), Fashion Studies: Research Methods, Sites and Practices (ss. 21 - 25). London: Bloomsbury Academic.

Johansson, A., \& Vinthagen, S. (2014). Dimensions of Everyday Resistance: An Analytical Framework. Critical Sociology, 42(3), 1 - 19

Kaiser, S. B., \& Green, D. N. (2016). Mixing Qualitative and Quantitative Methods in Fashion Studies: Philosophical Underpinnings and Multiple Masculinities. İçinde H. Jenss (Ed.), Fashion Studies: Research Methods, Sites and Practices (ss. 160 - 181). London: Bloomsbury Academic.

McRobbie, A. (2013). Postmodernizm ve Popüler Kültür. İstanbul: Parşömen Yayıncılık.

O’Neill, J. (2004). Five Bodies. London: Sage Publications.

Pitts, V. (2003). In The Flesh: The Cultural Politics of Body Modification, New York: Palgrave Macmillan.

Rudzinski, A., \& Orabona, S. (Yönetmenler). (2020). Savage X Fenty Show Vol. 2 [Film]. Amazon Studios.

Scott, J. (2014). Tahakküm ve Direniş Sanatları: Gizli Senaryolar. İstanbul: Ayrıntı Yayınları.

Simmel, G. (1957). Fashion. American Journal of Sociology. 62(6), 541 - 558.

Veblen, T. B. (2016). Aylak Sinıfin Teorisi: Kurumların Iktisadi İncelemesi. Ankara: Heretik Yayınları. 
Wearing, S. L, Wearing, J., McDonald, M., \& Wearing, M. (2015). Leisure in a world of 'com-pupu-pu-pu-pu-pu-pu-pu-pu-pu-puter-puter, puter games': a father and son conversation. Annals of Leisure Research, 18(2), 219 - 234.

Weitz, R. (2001). Women and Their Hair: Seeking Power through Resistance and Accommodation. Gender \& Society, 15(5), $667-686$.

Wilson, E. (2003). Adorned in Dreams: Fashion and Modernity. London: I. B. Tauris. 